\title{
Genotype Diversity and Spread of White Spot Syndrome Virus (WSSV) in Madagascar (2012-2016)
}

\author{
Alain Moïse Onihary 1,2,3, Iony Manitra Razanajatovo ${ }^{3,4}$, Lydia Rabetafika 2,3, Alexandra Bastaraud ${ }^{1}$, \\ Jean-Michel Heraud ${ }^{3,5, *}$ (D) and Voahangy Rasolofo ${ }^{3,6, *}$ \\ 1 Food and Environmental Hygiene Laboratory, Institut Pasteur de Madagascar, \\ Antananarivo 101, Madagascar; moise@pasteur.mg (A.M.O.); abastaraud@pasteur.mg (A.B.) \\ 2 Animal Biology Department, Faculty of Sciences, University of Antananarivo, \\ Antananarivo 101, Madagascar; rabetafikalaurence@gmail.com \\ 3 Ecole Doctorale Science de la Vie et de l'Environnement, Faculty of Sciences, University of Antananarivo, \\ Antananarivo 101, Madagascar; ionyr@pasteur.mg \\ 4 Virology Unit, Institut Pasteur de Madagascar, Antananarivo 101, Madagascar \\ 5 Virology Department, Fondation Institut Pasteur de Dakar, Dakar 12900, Senegal \\ 6 Scientific Direction, Institut Pasteur de Madagascar, Antananarivo 101, Madagascar \\ * Correspondence: jean-michel.heraud@pasteur.fr (J.-M.H.); vrasolof@pasteur.mg (V.R.); \\ Tel.: +221-77-09-235-44 (J.-M.H.); +261-20-22-412-72 (V.R.)
}

\section{check for}

updates

Citation: Onihary, A.M.; Razanajatovo, I.M.; Rabetafika, L.; Bastaraud, A.; Heraud, J.-M.; Rasolofo, V. Genotype Diversity and Spread of White Spot Syndrome Virus (WSSV) in Madagascar (2012-2016). Viruses 2021, 13, 1713. https:/ / doi.org/10.3390/v13091713

\section{Academic Editors: Manfred}

Weidmann, Mansour El-Matbouli, Sven M. Bergmann and Weiwei Zeng

Received: 18 June 2021

Accepted: 26 August 2021

Published: 28 August 2021

Publisher's Note: MDPI stays neutral with regard to jurisdictional claims in published maps and institutional affiliations.

Copyright: (c) 2021 by the authors. Licensee MDPI, Basel, Switzerland. This article is an open access article distributed under the terms and conditions of the Creative Commons Attribution (CC BY) license (https:// creativecommons.org/licenses/by/ $4.0 /)$.

\begin{abstract}
White Spot Disease (WSD) caused by the White Spot Syndrome Virus (WSSV) is the most devastating viral disease threatening the shrimp culture industry worldwide, including Madagascar. WDS was first reported on the island in 2012; however, little is known about the circulation of the virus and its genetic diversity. Our study aimed at describing the molecular diversity and the spread of WSSV in the populations of Madagascan crustaceans. Farmed and wild shrimps were collected from various locations in Madagascar from 2012 to 2016 and were tested for WSSV. Amplicons from positive specimens targeting five molecular markers (ORF75, ORF94, ORF125, VR14/15 and VR23/24) were sequenced for genotyping characterizations. Four genotypes were found in Madagascar. The type-I genotype was observed in the south-west of Madagascar in April 2012, causing a disastrous epidemic, then spread to the North-West coast. Type-II strains were detected in October 2012 causing an outbreak in another Penaeus monodon farm. In 2014 and 2015, types II and III were observed in shrimp farms. Finally, in 2016, types II and IV were found in wild species including Fenneropenaeus indicus, Metapenaeus monoceros, Marsupenaeus japonicus and Macrobrachium rosenbergii. Considering the economic importance of the shrimp industry for Madagascar, our study highlights the need to maintain WSSV surveillance to quickly take appropriate countermeasures in case of outbreak and to sustain this industry.
\end{abstract}

Keywords: White Spot Syndrome Virus (WSSV); aquaculture; Madagascar; genotype; virology

\section{Introduction}

White Spot Syndrome Virus (WSSV) is the only virus belonging to the genus Whispovirus within the Nimaviridae family [1]. WSSV is the causative agent of White Spot Disease (WSD) and it is the most significant viral pathogen of cultured shrimp [2]. This virus has a wide range of potential hosts [3], including lobsters, crayfish and crabs [3,4]. For instance, WSSV infection was found in a variety of marine crabs and spiny lobsters without significant loss or viral disease (WSSV carriers) [3-6]. However, a more recent study reported WSSV infection with clinical signs in some species of crabs and lobsters [7-9]. The clinical signs of the disease include lethargy, anorexia, white spots on the cuticle and, often, generalized reddish to pink discoloration [10]. This virus is highly contagious, and transmission can occur either horizontally through oral ingestion of infected prawns or contaminated water, or vertically from infected parents in hatcheries [11]. 
Since its first occurrence in China and Taiwan during 1991 to 1992 [12], the virus has spread rapidly through Asia [3,13], the Americas [14], Middle East, Africa [15,16] and Australia $[17,18]$. In cultured shrimps, WSSV infection can lead to a loss of up to 100\% within 1-10 days [19]. This is the most serious problem threatening the shrimp culture industry worldwide [2]. Economic losses due to this disease have been estimated at up to US $\$ 15$ billion, since its emergence in 1991, increasing at a rate of US $\$ 1$ billion annually [20,21]. Although these estimates are dated from more than 10 years ago, more recent data reported that the global shrimp sector lost US $\$ 6$ billion in 2016 due to viral diseases [22].

Madagascar is the fourth biggest island in the world with a total surface area of $587,295 \mathrm{~km}^{2}$ and is located in the south-west of the Indian Ocean. Shrimp farming was introduced in Madagascar in the early 1980s and most farms are located on the north-west coast of the country, along the Mozambican channel. Shrimp (captured and farmed) is the most valuable fishery in the country. Commercial shrimp farming represents an important resource for the economy of the country and provides many jobs [23]. In 1998, 16,000 MT (6000 MT from shrimp farming) of shrimps were produced in Madagascar, with a total value estimated at US \$54 million [24,25]. In 2012, production dropped to 4940 MT [25], not reaching the production levels of previous years. Interestingly, the first cases of WSD were reported in April 2012 in a farm located on the south-west coast of Madagascar [16]. This decrease in production could be attributed to the occurrence of WSD outbreak [25]. A few months later (September 2012), WSD was again detected in another shrimp farm located on the west coast. Furthermore, more farms located on the same axis were affected by WSD between 2012 and 2016. A previous study by Tang et al. [16] investigating the potential origins of the WSSV from the first farms affected by WSD in 2012 revealed that the WSSV found in Madagascar, Mozambique and Saudi Arabia were from a common source, probably the Indian Ocean and the Red Sea. To further explore the origins of the WSSV found in Madagascar, we conducted a study aiming at characterizing the genotypes of WSSV that circulated amongst cultured and wild shrimps between 2012 and 2016. This is the first report looking at the genetic diversity of WSSV present in commercial farms and wild shrimps in Madagascar.

\section{Materials and Methods}

\subsection{Specimen Collections}

Cultured Penaeus monodon and bycatch of Fenneropenaeus indicus were collected from five shrimp farms (Figure 1: S1 to S5). Wild crustaceans were collected from the mangrove swamps downstream of four shrimp farms (Figure 1: S1 to S5) and near the first farm infected, located in the district of Belo sur Tsiribihina (Figure 1: S1). The sampling was carried out from April 2012 to December 2016. Each sample consisted of whole juvenile or adult shrimps. All of them were preserved in $96 \%$ ethanol or by freezing until analysis at the Food and Environmental Hygiene Laboratory of the Institut Pasteur de Madagascar.

\subsection{Amplification and Detection of WSSV}

Total DNA was extracted from $25 \mathrm{mg}$ of shrimp pleopod using a Nucleospin ${ }^{\circledR}$ tissue Kit (Macherey-Nagel, Dueren, Germany) according to the manufacturer's protocol.

Screening and detection of WSSV were conducted according to standard protocols (Table 1) as described previously [13], with some modifications. The nested PCR was sensitive and allowed us to detect a light WSSV infection in wild shrimps or in cultured shrimps outside an epidemic period. The first-step PCR used 146F1 and 146R1 primers with an expected amplified fragment size of $1447 \mathrm{bp}$ (Table 1) in the SalI DNA fragment of the WSSV genome. The PCR reaction of the first step was carried out with $20 \mu \mathrm{L}$ of reaction mixture that consisted of $1 \mathrm{U}$ of Platinum Taq DNA polymerase (Invitrogen, Waltham, MA, USA), $1 \times$ PCR buffer (10 mM Tris- $\mathrm{HCl}, \mathrm{KCl} 50 \mathrm{mM}$, pH 9), $1.5 \mathrm{mM}$ of $\mathrm{MgCl}_{2}, 0.5 \mu \mathrm{M}$ of each primer, $0.2 \mathrm{mM}$ of dNTPs and $4 \mu \mathrm{L}$ of template DNA at $50 \mathrm{ng} \mu \mathrm{L}^{-1}$ and made up to volume using PCR grade distilled water. 


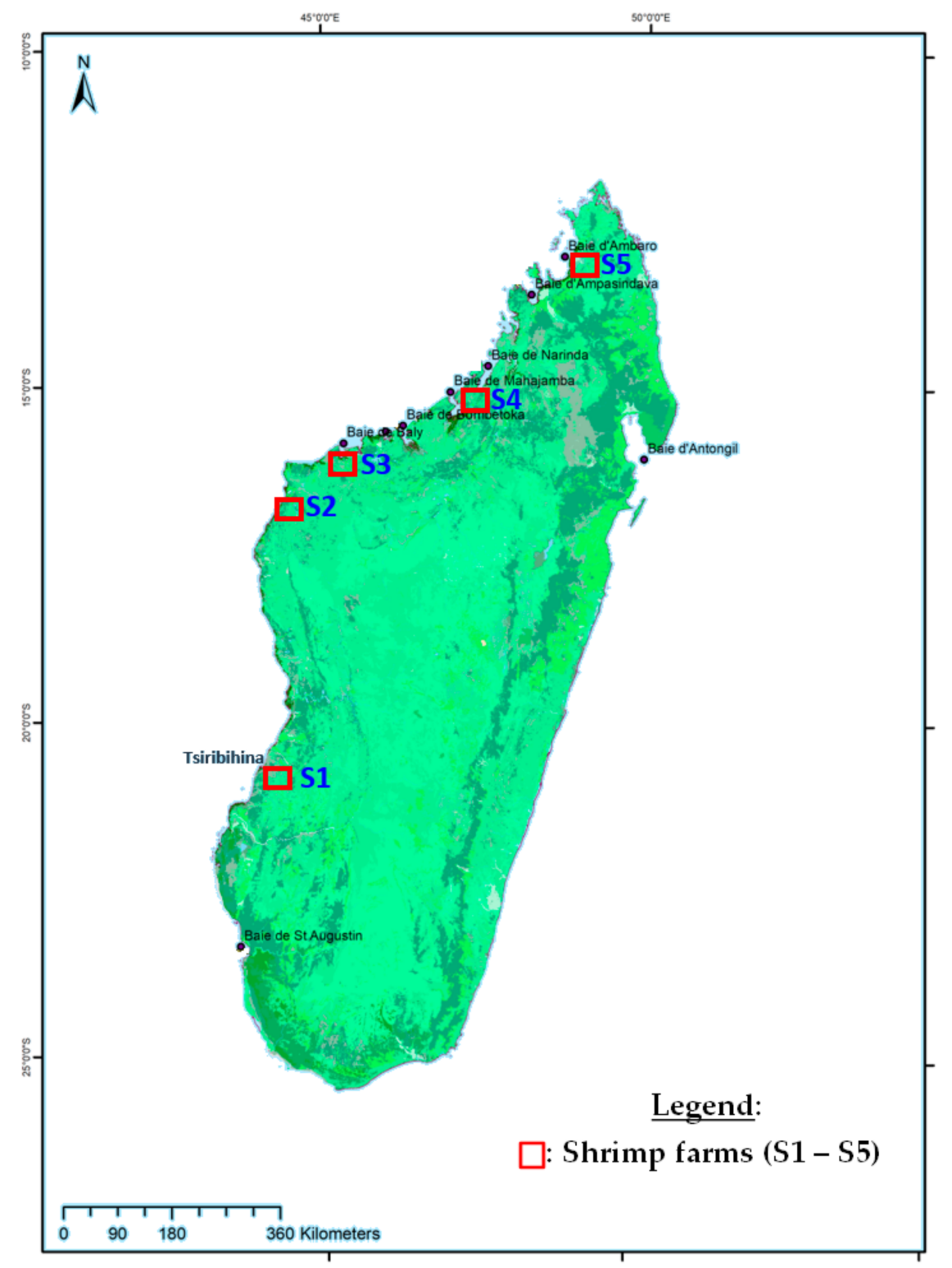

Figure 1. Sampling sites for crustaceans during the study. The Shrimp farms are located in Belo sur Tsiribihina (S1), Sambao estuary (S2), Baly bay (S3), Mahajamba bay (S4) and Ambaro bay (S5).

Primers 146F2 and 146R2 (Table 1) were used for nested (2 step) PCR to amplify a $941 \mathrm{bp}$ DNA fragment inside the first strand of $1447 \mathrm{bp}$ in the Sall. The nested PCR included $10 \mu \mathrm{L}$ of the first step reaction mixture, $1.25 \mathrm{U}$ of Taq DNA Polymerase, $1 \times$ PCR buffer, $1.5 \mathrm{mM}$ of $\mathrm{MgCl}_{2}, 1 \mu \mathrm{M}$ of each primer, $0.2 \mathrm{mM}$ of dNTPs and made up to $25 \mu \mathrm{L}$ using PCR grade distilled water.

Amplification was performed in a DNA Thermocycler (Biometra T-Gradient, Biometra, Gottingen, Germany). The first step was cycled using the following parameters: initial denaturation at $94{ }^{\circ} \mathrm{C}$ for $4 \mathrm{~min}, 55^{\circ} \mathrm{C}$ for $1 \mathrm{~min}, 72{ }^{\circ} \mathrm{C}$ for $2 \mathrm{~min}$ followed by 40 cycles of $94{ }^{\circ} \mathrm{C}$ for $1 \mathrm{~min}, 55{ }^{\circ} \mathrm{C}$ for $1 \mathrm{~min}, 72{ }^{\circ} \mathrm{C}$ for $2 \mathrm{~min}$, with a final extension at $72{ }^{\circ} \mathrm{C}$ for $5 \mathrm{~min}$. For the nested-PCR, the following conditions were used: 40 cycles of $94^{\circ} \mathrm{C}$ for $1 \mathrm{~min}$, $62{ }^{\circ} \mathrm{C}$ for $1 \mathrm{~min}, 72{ }^{\circ} \mathrm{C}$ for $2 \mathrm{~min}$ and a final extension at $72{ }^{\circ} \mathrm{C}$ for $5 \mathrm{~min}$. The PCR product $(10 \mu \mathrm{L})$ was mixed with $2 \mu \mathrm{L}$ of loading dye buffer and subjected to electrophoresis in $1.2 \%$ of agarose gel, containing $5 \%$ of ethidium bromide. Fragment sizes were determined using a $100 \mathrm{bp}$ DNA Ladder (GeneRuler, Thermo Scientific, Paisley, UK) and the gels were observed and photographed under UV light using Visioncapt (Transluminator, Biovision, Bengaluru, Karnataka, India). 
The DNA extracted from WSSV infected shrimp tissue from the University of Arizona was used as positive control. DNA from a WSSV negative field sample and sterile distilled water was used as the negative control.

\subsection{WSSV Genotyping}

WSSV-positive samples were amplified using three VNTR loci (ORF75, ORF94, and ORF125) and two variable regions (VR14/15, VR23/24). These five molecular markers have been used efficiently and widely for WSSV genotyping [26,27]. PCR reactions were performed in a final volume of $25 \mu \mathrm{L}$, containing $1.25 \mathrm{U}$ of Platinum Taq DNA polymerase (Invitrogen, Waltham, MA, USA), $1 \times$ PCR buffer (10 mM Tris- $\mathrm{HCl}, \mathrm{KCl} 50 \mathrm{mM}, \mathrm{pH}$ 9), $1.5 \mathrm{mM}$ of $\mathrm{MgCl}_{2}, 0.5 \mu \mathrm{M}$ of each primer, $0.2 \mathrm{mM}$ of dNTPs, $50 \mathrm{ng} \mathrm{LL}^{-1}$ of extracted DNA in $2.5 \mu \mathrm{L}$ volume and adjusted to $25 \mu \mathrm{L}$ with PCR grade distilled water. Amplification was performed according to previously described primers, with some modifications. We hypothesize that if no PCR products were detected, the targeting DNA fragment is missing in the WSSV genomic sequence. To ensure that the gene is deleted, we performed a new PCR with another set of primers, flanking the targeted genomic DNA sequence (Table 1).

\subsection{DNA Sequencing Analysis}

The PCR-amplified products were sequenced by "Genoscreen Services" for forward and reverse Sanger sequencing with the same primers used in the PCR reaction. Nucleotides sequences were edited and aligned using BioEdit Sequence Alignment Editor Software V7.1 program [28]. Consensus sequences were blasted to available genes and whole genome of WSSV downloaded from the NCBI website. The WSSV sequence of Thailand strain TH-96-II (GenBank Accession AY753327) was used as a reference for variable region VR14/15 analysis [29] and WSSV sequence of Taiwan strain WSSV-TW (GenBank Accession AF440570) was used for variable region VR23/24 [30]. The deletion sizes of these variable regions were then compared to WSSV strains described. The numbers of tandem repeats for VNTRs loci (ORF75, ORF94, ORF125) were analyzed using the Tandem Repeats Finder (TRF) program [31]. The same sequences of repeat fragments as described previously $[15,16,29,32-34]$ were used to describe WSSV strains: 45 bp and 102 bp repeat units (RUs) for ORF75, $54 \mathrm{bp}$ RU for ORF94 and $69 \mathrm{bp}$ RU for ORF125. The WSSV genotype was characterized as "N75, N94, N125, X14/15, X23/24" where N is the number of repeat units in a specific ORF and $\mathrm{X}$ is the number of base pair deletions in the variable region VR14/15, VR23/24. 
Table 1. Primers used and cycling conditions for WSSV screening and variable loci analysis. (ORF = Open reading frame, VR = Variable region).

\begin{tabular}{|c|c|c|c|c|c|c|}
\hline & Primers & Forward/Reverse Primers & Sequence $\left(5^{\prime}-3^{\prime}\right)$ & Cycling Conditions & PCR Product Size (bp) & References \\
\hline \multirow{2}{*}{$\begin{array}{c}\text { WSSV } \\
\text { screening }\end{array}$} & 146-1 (first step) & $\begin{array}{ll}146-\mathrm{F} 1 \\
\text { 146-R1 }\end{array}$ & $\begin{array}{l}\text { ACTACTAACTTCAGCCTATCTAG } \\
\text { TAATGCGGGTGTAATGTTCTTACGA }\end{array}$ & $\begin{array}{l}94{ }^{\circ} \mathrm{C} 4 \min , 55^{\circ} \mathrm{C} 1 \mathrm{~min}, 72{ }^{\circ} \mathrm{C} 2 \mathrm{~min} ; 40 \times\left[94^{\circ} \mathrm{C}\right. \\
\left.4 \mathrm{~min}, 55^{\circ} \mathrm{C} 1 \mathrm{~min}, 72^{\circ} \mathrm{C} 4 \mathrm{~min}\right] ; 72^{\circ} \mathrm{C} 5 \mathrm{~min}\end{array}$ & 1447 & \multirow{2}{*}{ [13] } \\
\hline & 146-2 (second step) & $\begin{array}{l}146-\mathrm{F} 2 \\
146-\mathrm{R} 2 \\
\end{array}$ & $\begin{array}{l}\text { GTAACTGCCCCTTCCATCTCCA } \\
\text { TACGGCAGCTGCTGCACCTTGT }\end{array}$ & $\begin{array}{c}40 \times\left[94{ }^{\circ} \mathrm{C} 1 \mathrm{~min}, 62^{\circ} \mathrm{C} 1 \mathrm{~min}, 72{ }^{\circ} \mathrm{C}\right. \\
2 \mathrm{~min}] ; 72^{\circ} \mathrm{C} 5 \mathrm{~min}\end{array}$ & 941 & \\
\hline \multirow{5}{*}{$\begin{array}{l}\text { Variable } \\
\text { loci } \\
\text { First PCR }\end{array}$} & ORF75-flank & $\begin{array}{l}\text { ORF75-flank-F } \\
\text { ORF75-flank-R }\end{array}$ & $\begin{array}{l}\text { GAAGCAGTATCTCTAACAC } \\
\text { CAACAGGTGCGTAAAAGAAG }\end{array}$ & $\begin{array}{c}94^{\circ} \mathrm{C} 4 \min ; 40 \times\left[94^{\circ} \mathrm{C} 1 \mathrm{~min}, 49 / 50{ }^{\circ} \mathrm{C} 80 \mathrm{~s},\right. \\
\left.72^{\circ} \mathrm{C} 1 \mathrm{~min}\right] ; 72^{\circ} \mathrm{C} 5 \mathrm{~min}\end{array}$ & 868 & [26] \\
\hline & ORF94 & $\begin{array}{l}\text { ORF94-F } \\
\text { ORF94-R }\end{array}$ & $\begin{array}{l}\text { TCTACTCGAGGAGGTGACGAC } \\
\text { AGCAGGTGTGTACACATTTCATG }\end{array}$ & $\begin{array}{c}94^{\circ} \mathrm{C} 3 \min ; 35 \times\left[94{ }^{\circ} \mathrm{C} 30 \mathrm{~s}, 55^{\circ} \mathrm{C} 30 \mathrm{~s},\right. \\
\left.72^{\circ} \mathrm{C} 1 \mathrm{~min}\right] ; 722^{\circ} \mathrm{C} 7 \mathrm{~min}\end{array}$ & 506 to 1262 & [33] \\
\hline & ORF125-flank & $\begin{array}{l}\text { ORF125 flank-F } \\
\text { ORF125 flank-R }\end{array}$ & $\begin{array}{l}\text { CGAAATCTTGATATGTTGTGC } \\
\text { CCATATCCATTGCCCTTCTC }\end{array}$ & $\begin{array}{c}94^{\circ} \mathrm{C} 3 \mathrm{~min} ; 35 \times\left[94{ }^{\circ} \mathrm{C} 30 \mathrm{~s}, 55^{\circ} \mathrm{C} 30 \mathrm{~s},\right. \\
\left.72^{\circ} \mathrm{C} 1 \mathrm{~min}\right] ; 72{ }^{\circ} \mathrm{C} 7 \mathrm{~min}\end{array}$ & 652 & [26] \\
\hline & VR14/15-complete & $\begin{array}{l}\text { VR14/15-complete-F } \\
\text { VR14/15-complete-R }\end{array}$ & $\begin{array}{l}\text { AATATGGAACGACGGGTG } \\
\text { GACCAGCGCCTCTTCAG }\end{array}$ & $\begin{array}{c}94^{\circ} \mathrm{C} 3 ; 35 \times\left[94^{\circ} \mathrm{C} 30 \mathrm{~s}, 50^{\circ} \mathrm{C} 30 \mathrm{~s},\right. \\
\left.72^{\circ} \mathrm{C} 2 \mathrm{~min}\right] ; 72^{\circ} \mathrm{C} 7 \mathrm{~min}\end{array}$ & 1851 & [29] \\
\hline & VR23/24-south & $\begin{array}{l}\text { VR23/24-south-F } \\
\text { VR23/24-south-R }\end{array}$ & $\begin{array}{l}\text { GTAGTGCATGTTTCTCTAAC } \\
\text { GTAAGTTTATTGCTGAGAAG }\end{array}$ & $\begin{array}{c}94^{\circ} \mathrm{C} 3 \min ; 35 \times\left[94{ }^{\circ} \mathrm{C} 30 \mathrm{~s}, 45^{\circ} \mathrm{C} 30 \mathrm{~s},\right. \\
\left.72^{\circ} \mathrm{C} 2 \mathrm{~min}\right] ; 72^{\circ} \mathrm{C} 7 \mathrm{~min}\end{array}$ & 1264 & [27] \\
\hline \multirow{5}{*}{$\begin{array}{l}\text { Variable } \\
\text { loci } \\
\text { Second } \\
\text { PCR }\end{array}$} & ORF73/ORF77 & $\begin{array}{l}\text { ORF73-F } \\
\text { ORF77-R }\end{array}$ & $\begin{array}{l}\text { CTTTCACCGCTCTCACCAAC } \\
\text { GGGTTCACCAGAGAGACAGG }\end{array}$ & $\begin{array}{c}94^{\circ} \mathrm{C} 3 \min ; 35 \times\left[94^{\circ} \mathrm{C} 30 \mathrm{~s}, 55^{\circ} \mathrm{C} 30 \mathrm{~s},\right. \\
\left.72^{\circ} \mathrm{C} 2 \mathrm{~min}\right] ; 72^{\circ} \mathrm{C} 7 \mathrm{~min}\end{array}$ & 1739 & [16] \\
\hline & ORF93/ORF96 & $\begin{array}{l}\text { ORF93-F1 } \\
\text { ORF96-R1 }\end{array}$ & $\begin{array}{l}\text { CGCCCTATTACCATTGATGC } \\
\text { GCAACAAATTCCCCTTTCAA }\end{array}$ & $\begin{array}{l}94{ }^{\circ} \mathrm{C} 4 \mathrm{~min} ; 40 \times\left[94{ }^{\circ} \mathrm{C} 1 \mathrm{~min}, 58^{\circ} \mathrm{C}\right. \\
\left.60 \mathrm{~min}, 72^{\circ} \mathrm{C} 1 \mathrm{~min}\right] ; 72{ }^{\circ} \mathrm{C} 5 \mathrm{~min}\end{array}$ & 348 & [15] \\
\hline & TJW14/15 & $\begin{array}{l}\text { TJW14/15-F } \\
\text { TJW14/15-R }\end{array}$ & $\begin{array}{l}\text { TCAACAACCCAAATCCCATT } \\
\text { CTCTCAATCTTCCСCСAACA }\end{array}$ & $\begin{array}{c}94{ }^{\circ} \mathrm{C} 3 \min ; 40 \times\left[94{ }^{\circ} \mathrm{C} 15 \mathrm{~s}, 60^{\circ} \mathrm{C} 15 \mathrm{~s},\right. \\
\left.72^{\circ} \mathrm{C} 1 \mathrm{~min}\right] ; 72^{\circ} \mathrm{C} 5 \mathrm{~min}\end{array}$ & 3343 & [34] \\
\hline & \multirow{2}{*}{ VR23/24-screen } & VR23/24-screen-F & CACACTTGAAAAATACACCAG & \multirow{2}{*}{$\begin{array}{c}94^{\circ} \mathrm{C} 3 \min ; 40 \times\left[94^{\circ} \mathrm{C} 15 \mathrm{~s}, 49^{\circ} \mathrm{C} 65 \mathrm{~s},\right. \\
\left.72^{\circ} \mathrm{C} 1 \mathrm{~min}\right] ; 72^{\circ} \mathrm{C} 5 \mathrm{~min}\end{array}$} & \multirow{2}{*}{548} & \multirow[t]{2}{*}{ [26] } \\
\hline & & VR23/24-screen-R & GTAAGTTTATTGCTGAGAAG & & & \\
\hline \multirow{4}{*}{$\begin{array}{l}\text { Variable } \\
\text { loci } \\
\text { Third PCR }\end{array}$} & ORF75 & $\begin{array}{l}\text { TJW75-F } \\
\text { TJW75-R }\end{array}$ & $\begin{array}{l}\text { TCTGAAGCTGGGGGAACTAA } \\
\text { GAGCAACTCTGCACAGCATC }\end{array}$ & $\begin{array}{c}94{ }^{\circ} \mathrm{C} 3 \min ; 40 \times\left[94{ }^{\circ} \mathrm{C} 15 \mathrm{~s}, 60^{\circ} \mathrm{C} 15 \mathrm{~s},\right. \\
\left.72^{\circ} \mathrm{C} 1 \mathrm{~min}\right] ; 72^{\circ} \mathrm{C} 5 \mathrm{~min}\end{array}$ & 702 & [34] \\
\hline & $\begin{array}{l}\text { VR23/24-south04 } \\
\text { VR23/24-1 }\end{array}$ & $\begin{array}{l}\text { VR23/24-south04-F } \\
\text { VR23/24-1-R }\end{array}$ & $\begin{array}{c}\text { CTACAACGGCCAAGTCAT } \\
\text { ATGATTGTATTCGTCGAAGG }\end{array}$ & $\begin{array}{c}94^{\circ} \mathrm{C} 3 \mathrm{~min} ; 40 \times\left[94{ }^{\circ} \mathrm{C} 15 \mathrm{~s}, 60^{\circ} \mathrm{C} 15 \mathrm{~s},\right. \\
\left.72{ }^{\circ} \mathrm{C} 1 \mathrm{~s}\right] ; 72{ }^{\circ} \mathrm{C} 5 \mathrm{~min}\end{array}$ & $1500 / 2000$ & [34] \\
\hline & \multirow{2}{*}{ ORF23/24 } & ORF23/24-F & GGTAGGAGAAGGTACGCACG & \multirow{2}{*}{$\begin{array}{c}94{ }^{\circ} \mathrm{C} 3 \min ; 40 \times\left[94{ }^{\circ} \mathrm{C} 30 \mathrm{~s}, 60{ }^{\circ} \mathrm{C} 15 \mathrm{~s},\right. \\
\left.72^{\circ} \mathrm{C} 1 \mathrm{~min}\right] ; 72^{\circ} \mathrm{C} 5 \mathrm{~min}\end{array}$} & \multirow{2}{*}{4025} & \multirow{2}{*}{ [35] } \\
\hline & & ORF23/24-R & GCCCAGATTGGTCATGTCCA & & & \\
\hline
\end{tabular}




\section{Results}

From April 2012 to December 2016, a total of 2184 specimens were collected and tested for the presence of WSSV. Among them, 503 were positive. These positive specimens were collected from five shrimp farms (Figure 1: S1 to S5) from 2012 to 2015 and in three mangroves swamps (Narinda bay, Mahajamba bay, Tsiribihina estuary) from 2014 to 2016.

\subsection{WSSV Screening and Genotyping}

We first screened the 503 positive samples with the ORF125 locus for genotyping. Of these, 308 samples gave four distinct PCR product sizes for this VNTR region (data not shown). From these 308 samples, samples with moderate to heavy infection (positive result in the first step PCR) were selected for further analysis. Forty (40) were then used for full genotyping with the five molecular markers. These samples were chosen according to their origin (cultured or wild shrimps), the sampling date and the host species. Of these 40 samples, 18 were from farmed shrimps and 22 from the wildlife. Sampling included 11 samples of Penaeus monodon, 21 of Fenneropenaeus indicus, 5 of Metapenaeus monoceros, 1 of Marsupenaeus japonicus and 2 of Macrobrachium rosenbergii (Table 2).

Table 2. Study samples, number of repeat units (No of RUs) in VNTRs regions (ORF75, ORF94, ORF125) and deletion size in variable regions (VR14/15, VR23/24) of WSSV.

\begin{tabular}{|c|c|c|c|c|c|c|c|c|c|}
\hline \multirow{2}{*}{ Site } & \multirow{2}{*}{ Type } & \multirow{2}{*}{ Host Species $^{1}$} & \multirow{2}{*}{ Sampling Date } & \multirow{2}{*}{$\begin{array}{l}\mathrm{Nb} \text {. of } \\
\text { Samples }\end{array}$} & \multicolumn{3}{|c|}{ Nb. of Repeat Units } & \multicolumn{2}{|c|}{ Deletion Size (bp) } \\
\hline & & & & & ORF75 & ORF94 $^{2}$ & ORF125 & VR14/15 & VR23/24 \\
\hline S1 & \multirow{8}{*}{ Farm } & P. monodon & April 2012 & 4 & 3 & del & 7 & 5950 & 10,971 \\
\hline \multirow{5}{*}{ S2 } & & P. monodon & September 2012 & 2 & 3 & del & 6 & 5950 & 10,971 \\
\hline & & P. monodon & December 2014 & 2 & 3 & del & 6 & 5950 & 10,971 \\
\hline & & P. monodon & May 2015 & 1 & 3 & del & 5 & 5950 & 10,971 \\
\hline & & F. indicus & November 2014 & 4 & 3 & del & 5 & 5950 & 10,971 \\
\hline & & F. indicus & November 2014 & 2 & 3 & del & 6 & 5950 & 10,971 \\
\hline \multirow{2}{*}{ S3 } & & P. monodon & October 2012 & 1 & 3 & del & 6 & 5950 & 10,971 \\
\hline & & F. indicus & October 2012 & 2 & 3 & del & 6 & 5950 & 10,971 \\
\hline \multirow{2}{*}{$\begin{array}{c}\text { Narinda } \\
\text { bay }\end{array}$} & \multirow{9}{*}{ Wild } & F. indicus & December 2016 & 1 & 3 & del & 6 & 5950 & 10,971 \\
\hline & & M. monoceros & December 2016 & 1 & 3 & del & 6 & 5950 & 10,971 \\
\hline \multirow{2}{*}{$\begin{array}{l}\text { Mahajamba } \\
\text { bay }\end{array}$} & & P. monodon & December 2016 & 1 & 3 & del & 6 & 5950 & 10,971 \\
\hline & & M. monoceros & December 2016 & 1 & 3 & del & 6 & 5950 & 10,971 \\
\hline \multirow{5}{*}{$\begin{array}{c}\text { Tsiribihina } \\
\text { estuary }\end{array}$} & & F. indicus & August 2016 & 8 & 3 & del & 6 & 5950 & 10,971 \\
\hline & & F. indicus & August 2016 & 4 & 3 & del & 8 & 5950 & 10,971 \\
\hline & & M. monoceros & August 2016 & 3 & 3 & del & 6 & 5950 & 10,971 \\
\hline & & M. japonicus & August 2016 & 1 & 3 & del & 6 & 5950 & 10,971 \\
\hline & & M. rosenbergii & August 2016 & 2 & 3 & del & 6 & 5950 & 10,971 \\
\hline
\end{tabular}

${ }^{1}$ P monodon: Penaeus monodon; F. indicus: Fenneropenaeus indicus; M. monoceros: Metapenaeus monoceros; M. japonicus: Marsupenaeus japonicus; M. rosenbergii: Macrobachium rosenbergii. ${ }^{2}$ del: deletion. ORF: Open Reading Frame; VR: Variable Region.

\subsection{VNTR Analysis of ORF125}

Four amplicons of 583 bp, 652 bp, 721 bp, and 792 bp (GenBank Accession MZ327619 to MZ327622, Supplementary Table S1) were generated with the amplification of ORF125. Sequences alignment and TRF program analysis of these amplicons showed 5, 6, 7 and 8 repeat units of $69 \mathrm{bp}$ fragments for $583 \mathrm{bp}, 652 \mathrm{bp}, 721 \mathrm{bp}$ and $792 \mathrm{bp}$ respectively. The number of samples showing these amplicon sizes was 5, 27, 4 and 4 respectively (Table 2). 


\subsection{VNTR Analysis of ORF94}

No PCR products were obtained using the primer ORF94-F and ORF94-R for all samples. A second PCR amplification targeting ORF93 and ORF96 genes was done using the couple of primers ORF93-F1/ORF96-R1 used by Tang et al. in 2013 [16] (Table 1). An amplicon of 348 bp (GenBank Accession MZ327623, Supplementary Table S1) was generated for the analysis of all forty samples. Sequencing and alignment using BLAST of this amplicon showed 99\% sequence identity with other WSSV sequences (WSSV-CN04, GenBank Accession KY827813; WSSV-TH, GenBank Accession AF369029 and WSSV-TW, GenBank Accession AF440570). Sequence analysis demonstrated that the 348 bp sequence matched with the sequence of ORF93 and ORF96 in these reference genomes. Thus, ORF94 and ORF95 were deleted for all Malagasy WSSV strains (Table 2).

\subsection{VNTR Analysis in ORF75}

PCR amplification of ORF75 with primers ORF75-flank-F/ORF75-flank-R [26] failed to produce PCR amplicons for all samples. Second amplification targeting ORF73 and ORF77 genes was done using the couple of primers ORF73-F and ORF77-R [16]. An amplicons of $1739 \mathrm{bp}$ (GenBank Accession MZ327624, Supplementary Table S1) were generated for 35 samples. No PCR product was detected for 5 samples. These same results were observed with a third PCR amplification using the primer set TJW75 as described by Piamsomboon et al. in 2018 [34] (Table 1). The 35 samples described above gave 702 bp amplicons and no PCR product for the five remaining samples.

Sequencing of the $1739 \mathrm{bp}$ amplicon and BLAST (Basic Local Alignment Sequences Tools) with WSSV DNA sequences available online showed $100 \%$ sequence identity with WSSV-CN04 (GenBank Accession KY827813). DNA sequence analysis using TRF program allowed us to confirm that 3 RUs of $45 \mathrm{bp}$ and $102 \mathrm{bp}$ were observed in these DNA sequences: two 45 bp RU and one 102 bp RU (Table 2).

\subsection{Deletion in VR14/15}

The first PCR using the primer set ORF14/15-complete [29] gave $1850 \mathrm{bp}$ amplicon (GenBank Accession MZ327625, Supplementary Table S1) for 20 samples out of the 40 samples. To investigate the reason for these negatives results, the two-step PCR as described previously by Piamsomboon et al. in 2018 [34] was applied to the samples. The first step used the primer set TJW14/15 and the second step used the primer set VR14/15-screen (Table 2). Amplicon sizes of $600 \mathrm{bp}$ were detected in 35 of 40 samples. The last five samples failed to produce PCR amplicons. Sequencing and alignment of the $1850 \mathrm{bp}$ amplicon using BLAST gave 100\% identity with WSSV-CN04 (GenBank Accession KY827813) and more than $99 \%$ with other WSSV sequences (WSSV-TH, GenBank Accession AF369029; WSSVTW, GenBank Accession AF440570). Compared to WSSV-TH-96-II reference sequence of $7800 \mathrm{bp}$ (GenBank Accession AY753327), the first $862 \mathrm{bp}$ are located in the $5^{\prime}$ region and the remaining $988 \mathrm{bp}$ are located in the $3^{\prime}$ region of the WSSV-TH-96-II. This indicated that Malagasy WSSV strains are characterized by a 5950 bp deletion size (Table 2, Figure 2).

\subsection{Deletion in VR23/24}

The primer set VR23/24-south [26] generated a PCR amplicon of 1265 bp (GenBank Accession MZ327626, Supplementary Table S1) for 26 of 40 samples. Other PCR amplifications were achieved for 14 out of 40 samples using the primers as described by Dieu et al. in 2004, Jiang et al. in 2017, and Piamsomboon et al. in 2018 [26,34,35] (Table 1). None of these PCR amplifications was unable to produce an amplicon for the 14 remaining samples. DNA sequence and alignment of the $1265 \mathrm{bp}$ amplicon with BLAST showed $100 \%$ identity with WSSV-CN04 (GenBank Accession KY827813). Compared to WSSV-TW (GenBank Accession AF440570), the $1017 \mathrm{bp}$ fragment is located in the $5^{\prime}$ region and $248 \mathrm{bp}$ were located in the $3^{\prime}$ region of the WSSV-TW sequence. This means that 10,971 bp were deleted for all Malagasy WSSV strains (Table 2, Figure 2). 


\section{(a) VR14/15}

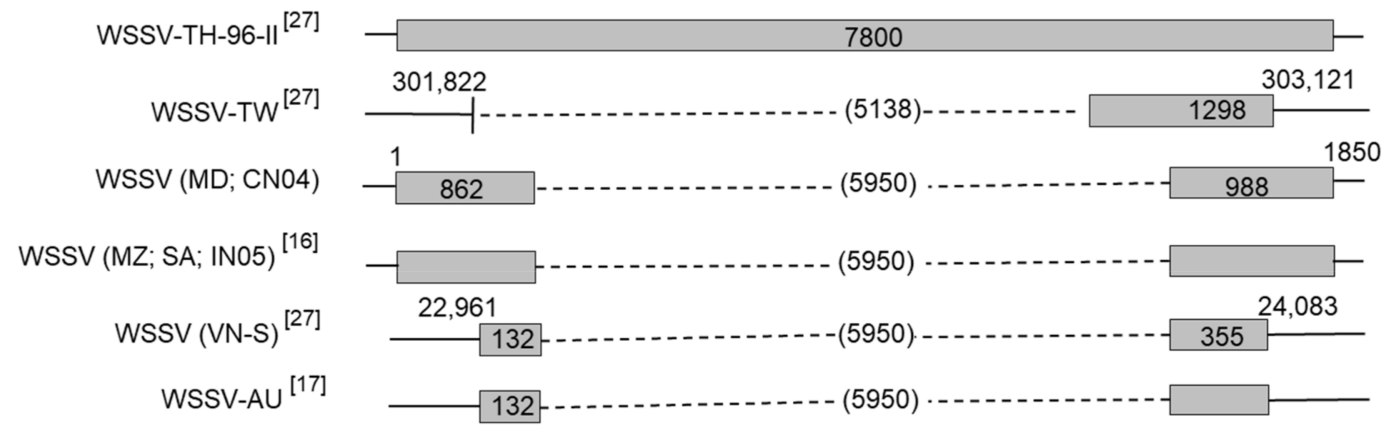

(b) VR23/24

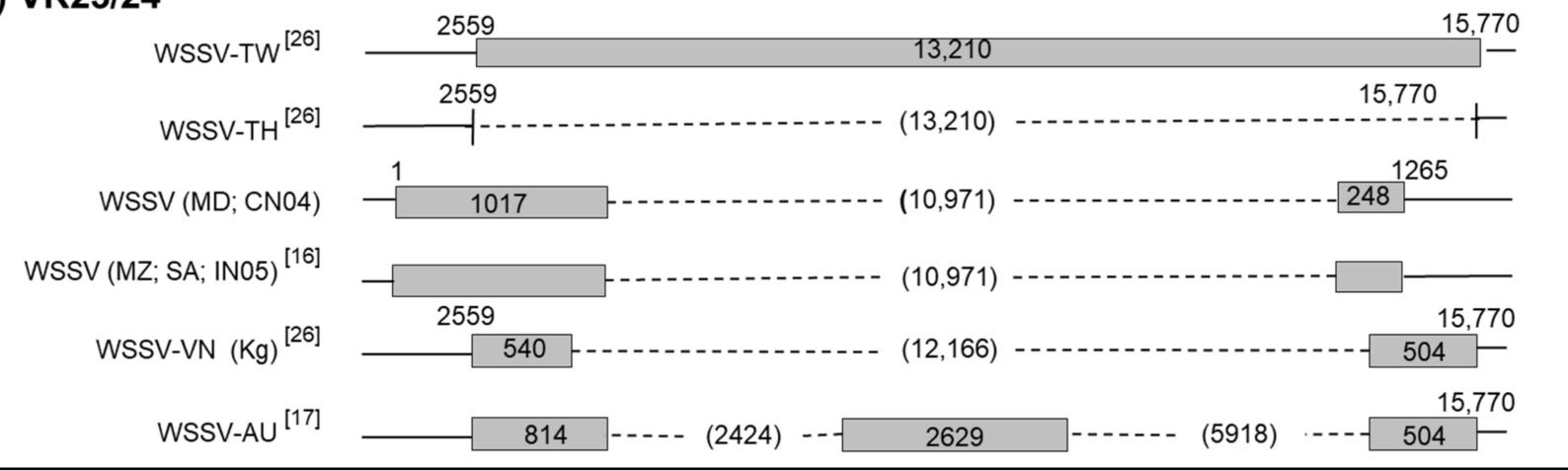

Figure 2. Schematic representation of the variable regions VR14/15 (a) and VR23/24 (b). Fragment lengths (bp) are described in boxes. Nucleotide position numbers in $5^{\prime}$ and $3^{\prime}$ regions are indicated above each strain according to GenBank sequences. Dashed lines indicate the deleted sequences. Deletion size is given in brackets. MD: Madagascar, MZ: Mozambique, SA: Saudi-Arabia, TH: Thaïland, TW: Taïwan, CN: China, VN: Vietnam, IN: India, AU: Australia (GenBank Accession MF768985).

\subsection{WSSV Genotype and Its Circulation}

Four WSSV genotypes were detected after molecular analysis of 40 different shrimp samples. The same genotype nomenclature as previously described was used in this study [16]. Each of them was designated as type I $\left(\left\{7_{125}, \mathrm{del}_{94}, 3_{75}, \Delta 5950_{14 / 15}, \Delta 10971_{23 / 24}\right\}\right)$, type II $\left(\left\{6_{125}\right.\right.$, del $\left.\left._{94}, 3_{75}, \Delta 5950_{14 / 15}, \Delta 10971_{23 / 24}\right\}\right)$, type III $\left(\left\{5_{125}\right.\right.$, del $_{94}, 3_{75}, \Delta 5950_{14 / 15}$, $\left.\left.\Delta 10971_{23 / 24}\right\}\right)$, and type IV $\left(\left\{8_{125}, \operatorname{del}_{94}, 3_{75}, \Delta 5950_{14 / 15}, \Delta 10971_{23 / 24}\right\}\right)$. These four genotypes differed in the number of $69 \mathrm{bp}$ RU in the ORF125 gene. Type II with 6 RU (ORF125-6) was observed in 27 of 40 samples and was detected in cultured as well as in wild shrimp species collected from 2012 to 2016. The three other WSSV variants, type I (ORF125-7), type III (ORF125-5) and type IV (ORF125-8), were detected sporadically in cultured or in wild shrimp species from 2012 to 2016. The first WSD outbreak in April 2012 was recorded in the south-west of Madagascar (S1) and was due to WSSV strain type I. WSSV type II was observed in September 2012 within S2 and S3 (Figure 2). In 2014 and 2015, type III appeared and was detected in four samples of P. monodon and F. indicus collected in S2 farm at the same time as type II. In 2016, type IV was detected in some wild F. indicus samples collected along the estuary of Tsiribihina, near S1 on the southern-west coast of Madagascar. Genotypes of WSSV on the west coast of Madagascar from 2012 to 2016 were mapped and simulated using microreact [36] (Figure 3). This microreact project can be visualized by sites of infection, by WSSV-genotypes or by host species (https:/ / microreact.org/project/eSrC2wJQrXgcxpKZvT4auZ/8432e8b4, accessed on 18 May 2021). 


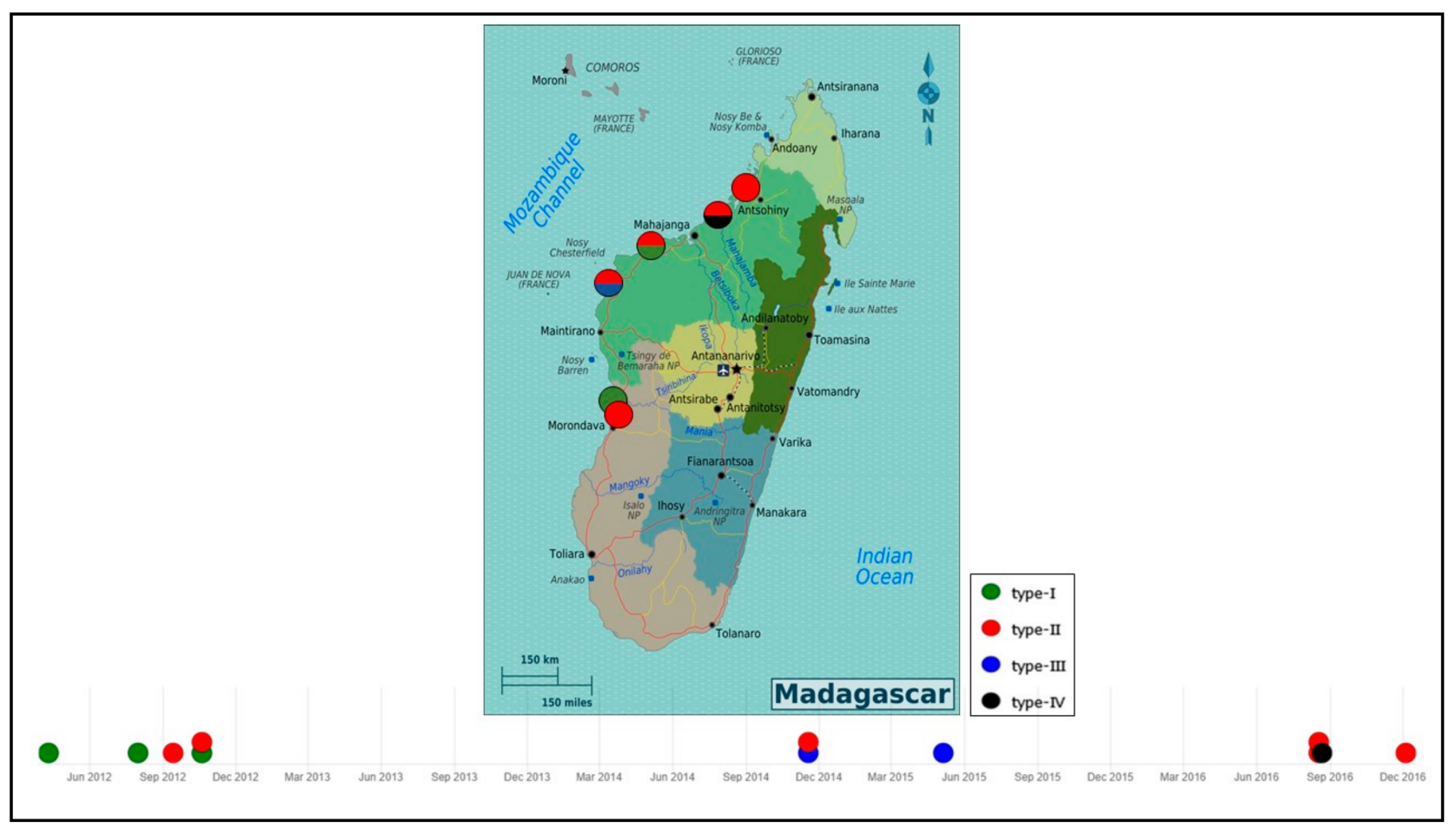

Figure 3. Genotypes of WSSV in the West coast of Madagascar from 2012 to 2016. WSSV genotypes are designed as type-I, type-II, type-III and type-IV (Simulation available at: https:/ / microreact.org/project/eSrC2wJQrXgcxpKZvT4auZ/8432e8 b4, accessed on 18 May 2021).

\section{Discussion}

Madagascar was free of WSSV until April 2012, according to the national WSSV surveillance plan conducted by the Malagasy authorities, in the wild and at all aquaculture sites. Since then, several species of wild and farmed shrimp have been found to carry WSSV. According to Tang et al. [16], the first genotype named type I $\left(\left\{7_{125}\right.\right.$, del $_{94}, 375, \Delta 5950_{14 / 15}$, $\left.\Delta 10971_{23 / 24}\right)$ was detected in the south-west of the country in April 2012, followed by type II $\left(\left\{6_{125}\right.\right.$, del $\left.\left._{94}, 3_{75}, \Delta 5950_{14 / 15}, \Delta 10971_{23 / 24}\right\}\right)$ in September 2012, in one farm closest to the first infected farm. In 2014 and 2015, WSSV type II and type III ( $\left\{5_{125}\right.$, del $_{94}, 3_{75}, \Delta 5950_{14 / 15}$, $\left.\left.\Delta 10971_{23 / 24}\right\}\right)$ were observed in other farms located further north of the previously infected farms. In 2016, type II and type IV $\left(\left\{8_{125}\right.\right.$, del $\left.\left._{94}, 3_{75}, \Delta 5950_{14 / 15}, \Delta 10971_{23 / 24}\right\}\right)$ were found in wild shrimp species from Mahajamba bay, Narinda bay and the estuary of Tsiribihina. These genotypes and mainly WSSV type II seemed to have spread progressively from the south to the north of the west coast of Madagascar and reached the mangrove areas. This pattern is similar to the Indian Ocean current that reaches Madagascar on the east coast and then from the south moves from south to north [37], related to the movement of crustaceans. Once the virus was present in the wild [16], the capture of spawners, the presence of healthy carriers in ponds (crabs or certain of species of barnacles attached to the gill of wild mud crab, lobsters, copepods and insect larvae) [38,39], or the probable use of contaminated water by pumping seawater, could explain the introduction of this virus into aquaculture sites. Certain species of seabirds observed around all farms in Madagascar have also been reported as potential sources of virus transmission [11]. In addition, the proximity of the shrimp farm to the sea is correlated with WSSV infection [40]. This could explain why no outbreaks of WSSV have been reported in the only shrimp farm (Figure 1: S5) located on the extreme north of Madagascar. These results suggest an evolution and local spread of WSSV on the west coast of Madagascar between 2012 and 2016.

In this study, two new genotypes are reported for the first time in Madagascar. These are WSSV type III $\left(\left\{5_{125}\right.\right.$, del $\left.\left._{94}, 3_{75}, \Delta 5950_{14 / 15}, \Delta 10971_{23 / 24}\right\}\right)$ and type IV $\left(\left\{8_{125}\right.\right.$, del $_{94}$, $\left.\left.3_{75}, \Delta 5950_{14 / 15}, \Delta 10971_{23 / 24}\right\}\right)$. While genotypes I and II were similar to those previously 
reported in Mozambique or Saudi Arabia, the types III and IV described here are different from the genotypes detected in Saudi Arabia $\left(\left\{8_{125}, 13_{94}, 3_{75}, \Delta 5950_{14 / 15}, \Delta 10971_{23 / 24}\right\}\right)$ and $\left(\left\{6_{125}, 794,375, \Delta 5950_{14 / 15}, \Delta 10971_{23 / 24}\right\}\right)[15,16]$. Arabian strains of WSSV had 13 and 7 RUs of $54 \mathrm{bp}$ in the ORF94 sequence, whereas the Malagasy strains had a complete deletion of ORF94. However, ORF125-8 and ORF125-6, with the same ORF75-3, $\Delta 5950_{14 / 15}$, $\Delta 10971_{23 / 24}$, were indeed previously reported in Saudi Arabia (2011) [15]. These results reinforce the hypothesis that the WSSV strains observed in Madagascar, Mozambique, and Saudi Arabia may have a common evolutionary origin.

We also found that the Malagasy strains (WSSV-MD) were genetically very similar to the Chinese strain (WSSV-CN04, Accession GenBank KY827813). The WSSV-CN04 had an identical deletion of $5950 \mathrm{bp}$ at VR14/15 and 10,971 bp at VR23/24 similarly to the Malagasy strains. Furthermore, the Australian (WSSV-AU, GenBank Accession MF768985) and Vietnamese (WSSV-VN-S) strains also carried a similar deletion size of $5950 \mathrm{bp}$ at VR14/15 compared to Malagasy strains. [17]. In addition, Malagasy and Australian strains shared the same RUs on VNTRs regions $\left(\left\{7_{125}\right.\right.$, del $\left.\left._{94}, 3_{75}\right\}\right)$. The variable regions (VR14/15 and VR23/24) and VNTR are used for global and regional molecular epidemiology, respectively [27,32]. These results suggest that the strains observed in Madagascar might share a common lineage with WSSV from China or Australia. In contrast, WSSV-CN04 had different RUs at VNTRs regions $\left(\left\{4_{94}, 6_{75}\right\}\right)$ compared to Malagasy strains (\{del $\left.\left.{ }_{94}, 3_{75}\right\}\right)$ and WSSV-AU showed two deletions of 2414 bp and 5918 bp at VR23/24 while WSSV-MD had a 10,971 bp deletion at this same locus. Comparative analysis of the whole genome of WSSV showed that Chinese and Australian strains are clustered together [17]. However, this whole genome approach could be biased by the presence of the large deletions [41]. In addition, it has been shown that adaptation of the virus to environmental conditions or passage to different host species subsequently favors the selection of different genotypes [42]. Thus, the source of the virus in Madagascar remains unclear. An alternative genotyping marker, selected according to our results and those described previously [41], could be used to better understand the genetic diversity and the source of WSSV.

This study demonstrated the effective use of previously described primers for molecular epidemiology of WSSV. The analysis of VNTRs (ORF75, ORF94 and ORF125) can be applied in Madagascar following the recommendations from several authors [16,26,27,33]. Indeed, these markers are useful for local molecular epidemiology [32]. The use on sequences of VR14/15 and VR23/24 increases the sensitivity of the genotyping of WSSV by PCR [16,34]. Specimens collected in 2014 from the northern part of the Island and mangrove areas had lower viral loads compared to those obtained during epidemic periods and in the south and west. For these low viral load specimens, the use of a nested PCR allowed detection of the virus. VR14/15 amplification, initially negative with conventional PCR amplification on some samples, yielded positive results by amplifying first with the TJW14/15 (first step) primers followed by a second PCR targeting the VR14/15 region, as reported by Piamsomboon et al. [34]. More strains were characterized using these primers and the results will serve as a solid basis for future research and needs in aquaculture. However, despite the use of this primer panel, some samples remained negative (including five samples for ORF75 and VR14/15, and 14 samples for VR23/24) even with a viral load ranging from moderate to severe. Therefore, a different approach should be developed, either by designing more sensitive primers for the detection of Malagasy strains or by implementing unbiased amplification such as the next generation sequencing approach.

Our study has some limitations. Indeed, following the outbreaks that affected the countries in 2012, it was difficult to receive regular specimens from the wild as well as from some aquaculture sites. Some farmers decided to do their testing abroad and we did not have access to the results of these tests. Our observation covers the period between 2012 and 2016 and we cannot exclude that the current situation has changed in terms of distribution and genotypic circulation. Analyses of a larger number of WSSV sequences collected from different locations and time periods (epidemic and non-epidemic) would identify all circulating genotypes in Madagascar and provide more details on 
the distribution and frequency of each genotype as well as the potential virulence of the different genotypes. Further analysis using an alternative genotyping method [41], combined with an experimental virulence study of each strain, could clarify some of the conflicting opinions. Indeed, some authors argue that the reduction in genome size is correlated with the virulence and pathogenicity of the virus [43]. In contrast, others argue that smaller genomes are not necessarily associated with higher mortality [44].

\section{Conclusions}

This study revealed that at least four distinct strains of WSSV are circulating in Madagascar, both in the wild and in aquaculture. The WSSV type I strain was responsible for the first outbreak in the southwestern part of Madagascar in 2012. The virus apparently spread from southern to northwestern Madagascar. The type II genotype appeared a few months later and was responsible for further outbreaks in different localities of the west coast. Genotypes III and IV were present in breeding species of P. monodon or species caught incidentally in breeding ponds such as $F$. indicus. These genotypes were also detected in the environment in several wild species of crustaceans (M. monoceros, M. japonicus, M. rosenbergii). Our results support a common origin of WSSV from Madagascar, Mozambique and Saudi Arabia as described previously and also suggest that Malagasy strains share a common lineage with the Chinese (WSSV-CN04) and Australian (WSSV-AU) strains, based on the similarity of the number of RUs in VNTRs regions and the similar size of the deletions for China and Madagascar.

We conclude that these three VNTRs markers and two variable regions are useful for local and large-scale epidemiological study. However, additional study would be needed to describe which of these genotypes are involved in the white spot outbreaks recorded almost every year in Madagascar from 2012 to 2020, as well as their virulence levels. New primers more specific to the strains observed in Madagascar could be added to those already used to describe the current situation on the big island with this pathogen. The hypothesis of new infestation from the same source should not be ruled out. An alternative genotyping method including whole genome sequencing of representative strains should be carried out in Madagascar for a more accurate in-depth epidemiological study. Experimental trials would be interesting to better understand the correlation between virulence and genome size.

As no effective vaccine or treatment is currently available against WSSV-associated infection, the aquaculture industry must adapt and evolve by monitoring all parameters that favor WSSV outbreaks. Control measures are based on risk management combined with strict biosecurity measures and an adequate surveillance plan for early detection of the virus, to reduce the impact on production. Currently, a significant progress is observed in the selection of WSSV-resistant shrimp strains in aquaculture sites. Thus, this study would be a significant advance in the selection of shrimp resistant to WSSV strains circulating in Madagascar.

Supplementary Materials: The following are available online at https:/ /www.mdpi.com/article/10 .3390/v13091713/s1, Table S1: GenBank Accession no. of DNA sequences used in this study.

Author Contributions: Conceptualization, A.M.O., I.M.R. and V.R.; Methodology, A.M.O.; WritingOriginal Draft Preparation, A.M.O.; Writing-Review and Editing; I.M.R., J.-M.H. and V.R.; Supervision, A.B., L.R., I.M.R. and V.R. All authors have read and agreed to the published version of the manuscript.

Funding: A.M.O. was supported though Girard's fellowship undergraduate program from the Institut Pasteur de Madagascar.

Conflicts of Interest: The authors declare no conflict of interest. 


\section{References}

1. Mayo, M.A. Virus taxonomy-Houston 2002. Arch. Virol. 2002, 147, 1071-1076. [PubMed]

2. Lillehammer, M.; Bangera, R.; Salazar, M.; Vela, S.; Erazo, E.C.; Suarez, A.; Cock, J.; Rye, M.; Robinson, N.A. Genomic selection for white spot syndrome virus resistance in whiteleg shrimp boosts survival under an experimental challenge test. Sci. Rep. 2020, 10, 20571. [CrossRef] [PubMed]

3. Flegel, T.W. Major viral diseases of the black tiger prawn (Penaeus monodon) in Thailand. World J. Microbiol. Biotechnol. 1997, 13, 433-442. [CrossRef]

4. OIE. Chapter 2.2.8. Infection with White Spot Syndrome Virus. In Manual of Diagnostic Tests for Aquatic Animals; World Organisation for Animal Health: Paris, France, 2021.

5. Lo, C.-F.; Ho, C.; Peng, S.; Chen, C.; Hsu, H.; Chiu, Y.; Chang, C.; Liu, K.; Su, M.; Wang, C.; et al. White Spot Syndrome Baculovirus (WSBV) detected in cultured and captured shrimp, crabs and other arthropods. Dis. Aquat. Org. 1996, 27, 215-225. [CrossRef]

6. Gopalakrishnan, A.; Rajkumar, M.; Sun, J.; Wang, M.; Senthil Kumar, K. Mud crab, Scylla tranquebarica (Decapoda: Portunidae), a new host for the white spot syndrome virus. Aquac. Res. 2011, 42, 308-312. [CrossRef]

7. Gunasekaran, T.; Gopalakrishnan, A.; Deivasigamani, B.; Seralathan, M.V.; Kathirkaman, P. Spontaneous white spot syndrome virus (WSSV) infection in mud crab (Scylla serrata Forskal 1775) fattening pens farm of south east coast of India. Comp. Clin. Path. 2018, 27, 413-419. [CrossRef]

8. Ross, E.P.; Behringer, D.C.; Bojko, J. White spot syndrome virus and the Caribbean spiny lobster, Panulirus argus: Susceptibility and behavioral immunity. J. Invertebr. Pathol. 2019, 162, 1-9. [CrossRef]

9. Diggles, B.K.; Chong, R.; Hawkins, K.; Underwood, D.; Genge, B.; Driver, L.; Kistler, C. Investigation into white spots in the carapace of a moribund mud crab (Scylla serrata) from a white spot syndrome virus (WSSV) positive zone in Moreton Bay, Australia. Aust. Vet. J. 2020, 98, 550-554. [CrossRef]

10. Durand, S.; Lightner, D.V.; Redman, R.M.; Bonami, J.R. Ultrastructure and morphogenesis of White Spot Syndrome Baculovirus (WSSV). Dis. Aquat. Org. 1997, 29, 205-211. [CrossRef]

11. Sanchez-Paz, A. White spot syndrome virus: An overview on an emergent concern. Vet. Res. 2010, 41, 43. [CrossRef]

12. Chou, H.; Huang, C.; Wang, C.; Chiang, H.; Lo, C. Pathogenicity of a baculovirus infection causing white spot syndrome in cultured penaeid shrimp in Taiwan. Dis. Aquat. Org. 1995, 23, 165-173. [CrossRef]

13. Lo, C.-F.; Leu, J.; Ho, C.; Chen, C.; Peng, S.; Chen, Y.-T.; Chou, C.; Yeh, P.; Huang, C.; Chou, H.; et al. Detection of baculovirus associated with white spot syndrome (WSBV) in penaeid shrimps using polymerase chain reaction. Dis. Aquat. Org. 1996, 25, 133-141. [CrossRef]

14. Lightner, D.V.; Redman, R.M.; Poulos, B.T.; Nunan, L.M.; Mari, J.L.; Hasson, K.W. Risk of spread of penaeid shrimp viruses in the Americas by the international movement of live and frozen shrimp. Rev. Sci. Tech. 1997, 16, 146-160. [CrossRef]

15. Tang, K.F.; Navarro, S.A.; Pantoja, C.R.; Aranguren, F.L.; Lightner, D.V. New genotypes of white spot syndrome virus (WSSV) and Taura syndrome virus (TSV) from the Kingdom of Saudi Arabia. Dis. Aquat. Org. 2012, 99, 179-185. [CrossRef]

16. Tang, K.F.; Le Groumellec, M.; Lightner, D.V. Novel, closely related, white spot syndrome virus (WSSV) genotypes from Madagascar, Mozambique and the Kingdom of Saudi Arabia. Dis. Aquat. Org. 2013, 106, 1-6. [CrossRef] [PubMed]

17. Oakey, H.J.; Smith, C.S. Complete genome sequence of a white spot syndrome virus associated with a disease incursion in Australia. Aquaculture 2018, 484, 152-159. [CrossRef]

18. Knibb, W.; Le, C.; Katouli, M.; Bar, I.; Lloyd, C. Assessment of the origin of white spot syndrome virus DNA sequences in farmed Penaeus monodon in Australia. Aquaculture 2018, 494, 26-29. [CrossRef]

19. Lightner, D.V. A Handbook of Shrimp Pathology and Diagnostic Procedures for Diseases of Cultured Penaeid Shrimp; World Aquaculture Society: Baton Rouge, LA, USA, 1996.

20. Lightner, D.; Redman, R.; Pantoja, C.; Tang, K.; Noble, B.; Schofield, P.; Mohney, L.; Nunan, L.; Navarro, S. Historic emergence, impact and current status of shrimp pathogens in the Americas. J. Invertebr. Pathol. 2012, 110, 174-183. [CrossRef] [PubMed]

21. Stentiford, G.; Neil, D.; Peeler, E.; Shields, J.; Small, H.; Flegel, T.; Vlak, J.; Jones, B.; Morado, F.; Moss, S.; et al. Disease will limit future food supply from the global crustacean fishery and aquaculture sectors. J. Invertebr. Pathol. 2012, 110, 141-157. [CrossRef] [PubMed]

22. Patil, P.K.; Geetha, R.; Ravisankar, T.; Avunje, S.; Solanki, H.G.; Abraham, T.J.; Vinoth, S.P.; Jithendran, K.P.; Alavandi, S.V.; Vijayan, K.K. Economic loss due to diseases in Indian shrimp farming with special reference to Enterocytozoon hepatopenaei (EHP) and white spot syndrome virus (WSSV). Aquaculture 2021, 533, 736231. [CrossRef]

23. Gillett, R. Global Study of Shrimp Fisheries; Food and Agriculture Organization of the United Nations: Rome, Italy, 2008; Volume 475, p. 331.

24. Goedefroit, S.; Chaboud, C.; Breton, Y. La ruée vers l'or rose: Regards croisés sur la pêche crevettière traditionnelle à Madagascar; IRD Editions: Paris, France, 2002.

25. Chamberlain, G.; Lightner, D.; Towner, R.; van Wyk, P.; Villarreal, M.; Akazawa, N.; Alvial, A. Case Study of the Outbreak of White Spot Syndrome Virus at Shrimp Farms in Mozambique and Madagascar: Impacts and Management Recommendations; Responsible Aquaculture Foundation: Portsmouth, NH, USA, 2013.

26. Dieu, B.T.M.; Marks, H.; Siebenga, J.J.; Goldbach, R.W.; Zuidema, D.; Duong, T.P.; Vlak, J.M. Molecular epidemiology of white spot syndrome virus within Vietnam. J. Gen. Virol. 2004, 85, 3607-3618. [CrossRef] [PubMed] 
27. Dieu, B.T.M.; Marks, H.; Zwart, M.P.; Vlak, J.M. Evaluation of white spot syndrome virus variable DNA loci as molecular markers of virus spread at intermediate spatiotemporal scales. J. Gen. Virol. 2010, 91, 1164-1172. [CrossRef]

28. Hall, T.A. BioEdit: A user-friendly biological sequence alignment editor and analysis program for Windows 95/98/NT. Nucleic Acids Symp. Ser. 1999, 41, 95-98.

29. Marks, H.; Van Duijse, J.J.A.; Zuidema, D.; Van Hulten, M.C.W.; Vlak, J.M. Fitness and virulence of an ancestral White Spot Syndrome Virus isolate from shrimp. Virus Res. 2005, 110, 9-20. [CrossRef] [PubMed]

30. Tsai, M.-F.; Yu, H.-T.; Tzeng, H.-F.; Leu, J.-H.; Chou, C.-M.; Huang, C.-J.; Wang, C.-H.; Lin, J.-Y.; Kou, G.-H.; Lo, C.-F. Identification and characterization of a shrimp white spot syndrome virus (WSSV) gene that encodes a novel chimeric polypeptide of cellulartype thymidine kinase and thymidylate kinase. Virology 2000, 277, 100-110. [CrossRef]

31. Benson, G. Tandem repeats finder: A program to analyze DNA sequences. Nucleic Acids Res. 1999, 27, 573-580. [CrossRef]

32. Dieu, B.T.M.; Zwart, M.P.; Vlak, J.M. Can VNTRs be used to study genetic variation within white spot syndrome virus isolates? J. Fish Dis. 2010, 33, 689-693. [CrossRef]

33. Wongteerasupaya, C.; Pungchai, P.; Withyachumnarnkul, B.; Boonsaeng, V.; Panyim, S.; Flegel, T.; Walker, P. High variation in repetitive DNA fragment length for White Spot Syndrome Virus (WSSV) isolates in Thailand. Dis. Aquat. Org. 2003, 54, $253-257$. [CrossRef]

34. Piamsomboon, P.; Chaweepack, T.; Han, J.E.; Tang, K.F.; Wongtavatchai, J. Genetic variation of white spot syndrome virus (WSSV) in Pacific white shrimp Litopenaeus vannamei (Boone 1931) culture of Thailand. Aquac. Res. 2018, 49, 265-272. [CrossRef]

35. Jiang, L.; Xiao, J.; Liu, L.; Pan, Y.; Yan, S.; Wang, Y. Characterization and prevalence of a novel white spot syndrome viral genotype in naturally infected wild crayfish, Procambarus clarkii, in Shanghai, China. Virus Dis. 2017, 28, 250-261. [CrossRef]

36. Argimón, S.; AbuDahab, K.; Goater, R.J.E.; Fedosejev, A.; Bhai, J.; Glasner, C.; Feil, E.J.; Holden, M.; Yeats, C.A.; Grundmann, H.; et al. Microreact: Visualizing and sharing data for genomic epidemiology and phylogeography. Microb. Genom. 2016, 2, e000093. [CrossRef] [PubMed]

37. République Fédérale Islamique des Comores. Atlas des Ressources Côtières de l'Afrique Orientale; Programme des Nations Unies pour l'Environnement: Nairobi, Kenya, 2002.

38. Sangamaheswaran, A.P.; Jeyaseelan, M.J.P. White Spot Viral Disease in Penaeid Shrimp-A Review. Naga, ICLARM Q. 2001, 24, 16-22.

39. PriyanghaS, J.; Gopalakrishnan, A.; MuhilVannan, S.; Gunasekaran, T.; Somasundaram, S.T. First report of pedunculate barnacle (Octolasmis neptuni), as potential asymptomatic carrier of white spot syndrome virus (WSSV). Comp. Haematol. Int. 2020, 29, 631-638.

40. Mohan, C.V.; Phillips, M.J.; Bhat, B.V.; Umesh, N.R.; Padiyar, P.A. Farm-level plans and husbandry measures for aquatic animal disease emergencies. Rev. Sci. Tech. 2008, 27, 161-173. [CrossRef]

41. Oakey, J.; Smith, C.; Underwood, D.; Afsharnasab, M.; Alday-Sanz, V.; Dhar, A.; Sivakumar, S.; Hameed, A.S.S.; Beattie, K.; Crook, A. Global distribution of white spot syndrome virus genotypes determined using a novel genotyping assay. Arch. Virol. 2019, 164, 2061-2082. [CrossRef]

42. Waikhom, G.; John, K.R.; George, M.R.; Jeyaseelan, M.J.P. Differential host passaging alters pathogenicity and induces genomic variation in white spot syndrome virus. Aquaculture 2006, 261, 54-63. [CrossRef]

43. Hoa, T.T.T.; Zwart, M.P.; Phuong, N.T.; De Jong, M.C.M.; Vlak, J.M. Low numbers of repeat units in variable number of tandem repeats (VNTR) regions of white spot syndrome virus are correlated with disease outbreaks. J. Fish Dis. 2012, 35, 817-826. [CrossRef] [PubMed]

44. Li, F.; Gao, M.; Xu, L.; Yang, F. Comparative genomic analysis of three white spot syndrome virus isolates of different virulence. Virus Genes 2017, 53, 249-258. [CrossRef] [PubMed] 